\title{
Psychological Contracts: Framework for Relationships in Construction Procurement
}

\author{
Peter R. Davis ${ }^{1}$, Marcus Jefferies ${ }^{2}$, and Yongjian $\mathrm{Ke}^{3}$
}

\begin{abstract}
The existence of psychological contracts (PC) in construction procurement is examined. Specific objectives are to identify the presence of the PC in construction project teams and catalogue its effect on procurement delivery. A survey instrument designed with the assistance of two focus groups and subsequently administered to a purposive sample of experienced construction/engineering managers identified unique attributes of significance. Two further focus groups helped develop a conceptual model of PC for construction of a more generalizable nature. Findings suggest PCs are present in construction delivery teams. Antecedent enabling factors, referred to as relational conditions and benefits that form unwritten agreements and unwritten contracting behaviors, are found, which consequently affect team satisfaction. For the professional, advances in knowledge are identified in the new model where factors of trust, commitment, and good faith and fair dealing are described as components of the $\mathrm{PC}$ in construction. Revealing these less tangible characteristics of construction management in the PC serves to provide the professional with a novel framework from which to anchor their understanding of procurement teams and enhance their decision-making capability.
\end{abstract}

Keywords: Psychological contracts; Construction procurement; Behavior; Organizational issues

\section{Introduction}

The construction industry is important to Australia; in 2010-2011 it was the third largest contributor to the Australian gross domestic product (GDP) and the third largest employer, with $\$ 167$ billion of construction work undertaken (in volume terms) (Australian Bureau of Statistics 2012). Despite this, Australian construction appears inefficient when compared with the United States and the United Kingdom (Productivity Commission 2014). A major contributing factor is poor relationships that exist within the industry (Davis and Love 2011; Davis and Walker 2009). Many Australian construction firms realize the strategic importance of relationship style contracting in accordance with Boukendour and Hughes (2014), Smiley et al. (2014), and Taggart et al. (2014). Effective participation in relationship development and the avoidance of traditional business-as-usual thinking has the potential to significantly enhance project outcomes (Love et al. 2010). For example, privatesector clients are calling for more integrated and collaborative forms of procurement, such as alliances or public private partnerships (PPP) (Anderson and Narus 1998; Bresnen 2009; LloydWalker et al. 2014). Despite this, it is clear that Australian firms have been slow adopters and those that have participated have problems articulating evident benefits.

A working knowledge of psychological contracts (PCs) has potential. A PC is an unwritten contract with mutual obligations as the central issue. It fills gaps in relationships and shapes employee behavior and surfaces unwritten expectations as opposed to contractual expectations (Anderson and Narus 1998). An example is "long term ... prospects" which are articulated outside a contract or

\footnotetext{
${ }^{1}$ Professor, Construction Management, School of Architecture and Built Environment, Faculty of Engineering and Built Environment, Univ. of Newcastle, Callaghan, NSW 2308, Australia (corresponding author). ORCID: http://orcid.org/0000-0002-9991-4413. E-mail: peter.davis@newcastle.edu.au

${ }^{2}$ Senior Lecturer, Construction Management, School of Architecture and Built Environment, Faculty of Engineering and Built Environment, Univ. of Newcastle, Callaghan, NSW 2308, Australia. E-mail: marcus.jefferies@newcastle.edu.au ${ }^{3}$ Senior Lecturer, Project Management, School of the Built Environment, Univ. of Technology Sydney, Ultimo, NSW 2007, Australia. E-mail: yongjian.ke@uts.edu.au
} 
written agreement (Anderson and Narus 1998). PCs are analogous to an internal motivator, and they drive individuals to identify a perceived or institutional contract that is often a departure from a written or more formal document of governance or contract. A PC can be characterized as either transactional or relational over a number of dimensions: their focus, time frame, inherent stability, overall scope, and tangibility (Anderson and Narus 1998).

In context it is appropriate for this research to adopt the concept of the $\mathrm{PC}$ as evident from the relational contract theory (RCT), which was originally developed by Macneil $(1973,1978)$, and has been widely adopted in construction research (Ling et al. 2014; Ning and Ling 2015). Consistent with the PC, RCT considers contracts to be relationships among the parties in the process of projecting exchange into the future, and states that informal agreements and unwritten codes of conduct exist among contracting partners, and these are sustained by the value of future relationships (Macneil 1978). However, RCT theorized that ten common contract behavior norms (including contractual and noncontractual norms) constitute an abstract summary of the variety of specific norms found in the many different forms of contracts. Because this study focuses on unwritten contracting behavior, PC is more appropriate than RCT.

There is considerable research regarding PCs; the literature provides examples of a theoretical framework in strategic supplier partnering (Blancero and Ellram 1997), buyer-supplier relationships (Hill et al. 2009), supplier-distributor relationships (Kingshott and Pecotich 2007), customer service relations strategy (Cutcher 2008), performance management (Stiles et al. 1997), and workplace safety (Walker and Hutton 2006). There is little research, however, within a construction management context focusing on procurement. Following Dainty et al. (2004) and more particularly Hill et al. (2009) and Blancero and Ellram (1997), it is proposed that an increased understanding of PC would provide procurement/delivery teams the ability to identify the nuances associated with relationship development in construction procurement and stakeholder engagement more successfully. This paper aims to identify the presence of PCs in construction project delivery and describe the affect that PCs have on organizational teams in procurement delivery.

The paper is structured as follows: an overview of the concept and background of PCs is presented. The general nature of the intra-organizational PC is discussed, with a working definition of the PC provided. This is followed by a section describing the PC as a personal deal. Finally, the PC with respect to suppliers/buyers in construction firms is explored. The research strategy is a mixed methods approach and is described together with a summary of the research instrument utilised. Results and discussion are presented together with a conceptual model of the PC in construction procurement. Concluding comments and limitations of the research together with opportunities for further research conclude the work.

\section{PCs}

\subsection{Background}

The term psychological contract first gained popularity in human resource studies during the 1990s (Guest and Conway 1997; Rousseau 1990, 1995; Sparrow and Marchington 1998). Sometime later, Dainty et al. (2004) investigated the PCs displayed by construction project managers, investigating the dynamics that govern the PC between construction project managers and employees in order to understand its influence on employee turnover. Later, strategic human resource management research identified that an understanding based on trust in the traditional PC was being undermined by "widespread organisational expansion and flattening organisational structures" (Raiden et al. 2009 , p. 78). It was noted that personal assessments had the potential for inconsistency and 
disillusioned employees through a violation of the PC (Raiden et al. 2009, p. 84). As a result, a more flexible approach, where an individual's preferences and expectations were taken into account, was recommended for construction organizations looking to maximize productivity (Raiden et al. 2009, p. 83; Dainty and Loosemore 2012, p. 24). They noted intrinsic rewards were becoming more important in the job market, citing examples that suggested the PC "may offer scope for creativity, innovation and a feeling of long term impact on the environment, (indeed) 'the desire to make something that will last' (Project Director)" (Dainty and Loosemore 2012, p. 258).

Beyond this, studies centered on the application of the PC in construction have been scant (Walker 2010, 2013; Walker and Hutton 2006), with an exception specifically associated with PCs and workplace safety in a construction context (Newaz et al. 2016).

\subsection{Intra-organizational PC}

The basis of the PC relationship within a firm is reciprocity between the organization and employees in terms of the perceived obligations and expectations between one another (Guest and Conway 2002), providing a good fit for the project delivery organization that is the basis of this study. The main theoretical underpinnings of the concept are generally attributed to Rousseau $(1990,1995)$, who distinguishes between two types of PC:

1. Transactional contracts involve specific, monetizable exchanges between parties over a finite and often brief period - for example, competitive wage rates and the absence of long-term commitments (Robinson et al. 1994, p. 139).

2. Relational contracts which, in contrast, involve open-ended, less specific agreements that establish and maintain a relationship. These contracts involve both monetizable and nonmonetizable exchanges. For example, inducements in relational contracts characteristically include training and development opportunities and a long-term career path within a firm (Robinson et al. 1994, p. 139).

Following this, a relational psychological contract provides a good match for the organizational perspective that forms the focus of this research.

It becomes clear that because the PC evolves around individual beliefs and perceptions, it is highly subjective and can be particular to each employee (Rousseau 1995). In essence, the PC constitutes an unwritten agreement between the organization and employees based on mutually accepted promises and obligations among the organization and the employees (Sparrow and Marchington 1998).

\subsection{PC as Personal Deal in Employee-Employer Relations}

One of the major arguments in PC theory is whether it can be regarded as a contract in comparison to formal contracts that have stipulated content with clear-cut parameters (Arnold 1996). Contrary views argue that a PC offers a perspective on a more realistic basis according to the parties' perceptions and can therefore have a greater influence than a formal contract (CIPD 2003). Sparrow and Marchington (1998) suggested that interaction between employment contracts and the PC affected legal terms and conditions, together with perceptions of obligation. In terms of strict comparison, a PC is an implicit reflection of the employment relationship resembling a legal contract, but on a broader scale. In the instance of a breach of a PC, adverse effects may manifest in the procurement organization and employees, and these are similar to the effect of penalties in more formal contract breaches (Deery et al. 2006). There are differences between the two contractual concepts, but the similarities are enough to justify the use of the term psychological contract to signal its authority in employee relations. 
Following this argument, Sparrow and Marchington (1998), Rousseau (1998), and Guest and Conway (1998), suggested the PC is a means to understanding the overall state of an organizational employment relationship. They posit that the PC should be regarded as a tool through which management can establish and maintain a healthy PC, and that change could subsequently be instituted more easily and with increased levels of commitment and satisfaction when new employment practices are adopted (Guest and Conway 1998, 2004). For example, Guest and Conway (1998) used employee perceptions of trust in management and whether employees felt they were fairly treated to measure the extent to which employees believed that promises made on behalf of the organization had been fulfilled. In the context of their study, they concentrated not on pinpointing the original promises made but on confirming that the important outcome was that employees believed promises had been made, thereby influencing the contractual nature that is subscribed to in this paper.

\subsection{Application of PC between Buyers and Suppliers}

In this paper, PC refers to unwritten agreements and behaviors between a construction firm and its upstream or downstream procurement partners. The premise provided by both Hill et al. (2009) and Blancero and Ellram (1997) is adopted in as much as the relationship between employees and employers discussed in the previous sections may be applied to that between individuals and buyers/suppliers (procurement partners). For example, Blancero and Ellram showed this clearly when they stated, "Typically described as the relationship between employees and employers, this construct can be projected on to other relationships as well, including the relationship between buyers and suppliers" (Blancero and Ellram 1997, p. 616). For example, in construction buyersupplier procurement relationships, this may be typified by suppliers or subcontractors working hard to meet their customers' expectations and requirements and hoping for continued business for their effort. Essentially, an improved understanding of the role the PC plays in buyer-supplier relationships holds great promise for enhancing the quality and performance of interfirm business partnerships (Hill et al. 2009, p. 291).

\section{Research Approach, Method, and Sample}

An extensive literature review identified a paucity of $\mathrm{PC}$ knowledge in construction concerning the effect the PC has on construction project delivery. However, on the basis that a PC is an unwritten contract containing mutual obligations shaping employee behavior, a PC most likely exists (Anderson and Schalk 1998). Consequently, specific research objectives were to

- Identify the presence of PCs in construction projects; and

- Describe, using two focus groups, the effect that psychological contracts have on organizational teams in procurement delivery.

The research method is presented in Fig. 1. The literature review provided the background for the initial Focus Groups 1 and 2. These sessions were conducted with industry stakeholders that comprised Tier 1 contracting organisations from New South Wales, Australia. A primary research question together with a robust critique of a preliminary survey instrument adapted from Leuthesser and Kohli (1995), Morgan and Hunt (1994), Gundlach et al. (1995), and Rousseau (1996) was undertaken. Subsequently, a pilot survey and then the final survey were administered online via Survey Monkey to a sample of 109 construction managers involved with project delivery. The sample was established with careful consideration of the population. Because the information solicited required in-depth knowledge and sound experience about project delivery, a purposive 
approach was adopted to select experts who could satisfy at least one of the following criteria following Krueger and Casey (2000):

- Criterion 1: Have extensive working experience in construction projects in Australia;

- Criterion 2: Have current/recent and direct involvement in project procurement of construction projects in Australia; and

- Criterion 3: Have a sound knowledge and understanding of the delivery of construction projects.

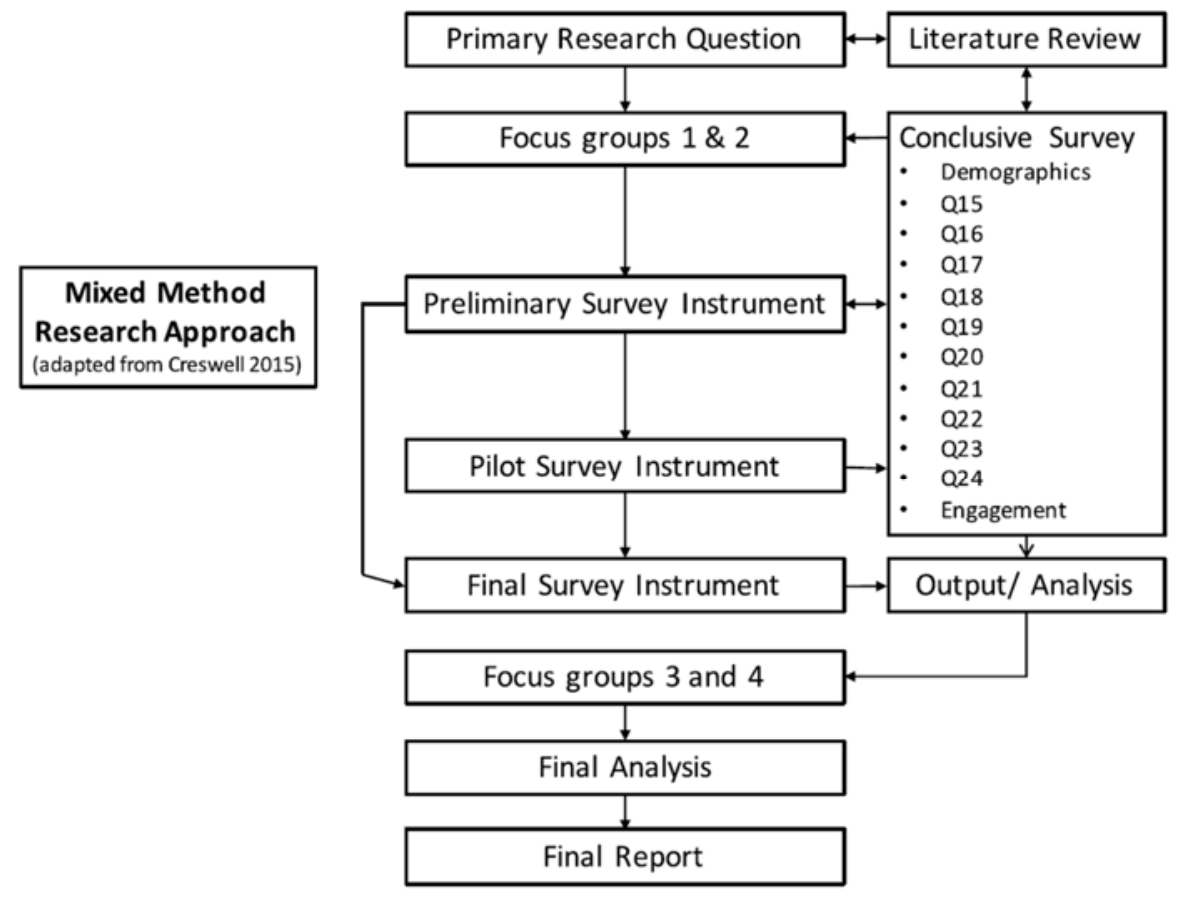

Fig. 1. Mixed-method research approach

The conclusive survey comprised 25 questions (herein after denoted as Q1-Q25):

1. Q1-Q8 were designed to obtain general background demographics about respondents.

2. Q9-Q13 determined project specifics (for example, type of facility and project value) and procurement method.

3. Q14 determined the duration of the relationship associated with their partnership in project delivery.

4. Q15-Q17 measured relational orientation using a scale adapted from Leuthesser and Kohli's (1995) original instrument designed to determine the extent of initiating (Q15), signalling (Q16,) and disclosing (Q17) behaviors - essentially, the extent that partners reveal sensitive information about themselves and all of their operations. The items in the scale reflected perceptions about the partner across these constructs in the early phases of a relationship. In the conceptual model these are described as Unwritten Contracting Behaviors. Importantly, these closely align with more recent construction management research that identified collaborative goal setting and trust benefits to the procurement team's engagement on relational style and alliance procurement (Davis and Love 2011; Davis 2005).

5. Q18 focussed on the respondent's perception of their procurement partner's satisfaction while working with them on a recent project. Research by Davis and Love (2011) determined a strengthening link between relational behaviours and satisfaction when the product (the longterm outcome that the team is anticipating to deliver) is important and the organizational environment is more dynamic. 
6. Q19 measured trust items using Morgan and Hunt's (1994) scales specifically developed to understand perceptions of suppliers in a procurement relationship. The measure of trust captures the level of reliability, integrity, and confidence within the relationship.

7. Q20 reviewed respondent commitment that represents the importance of and beliefs about maintaining the relationship. This measure reflects attitudinal element of commitment proposed by Gundlach et al. (1995) revealing a buyers' disposition toward a supplier firm (Morgan and Hunt 1994). These constructs are described as Unwritten Agreement in the conceptual model. Psychological contracts were measured with four factor scales adapted from Rousseau's (1996) extensive work to examine the extent to which employees believed certain intrinsic/extrinsic promises are made in dealing with their major partners. The four factors were

- Q21, good faith and fair dealing (part of Unwritten Agreement);

- Q22 relational benefits;

- Q23 relational conditions; and

- Q24 intrinsic relational characteristics which are described as Relational Conditions and Benefits in the Conceptual Model.

8. Q25 related to the respondents' interest in receiving further updates on the research.

All items in these measures used a 5-point Likert scale with strongly disagree and strongly agree as anchors (Bryman 2004). Statistical methods used were descriptive statistics and one-sample t-test. Zumbo and Zimmerman (1993, p. 390) stated that "there is no need to replace parametric statistical tests by nonparametric methods when the scale of measurement is ordinal and not interval." This study therefore conducted the parametric statistical test, the one-sample t-test, on the items in the survey to determine if the respondents embraced them to a significant extent. The test value was set at 3 , which is the mean of a 5-point Likert scale. When $p<0.05$ it was concluded that the factors/behaviours/agreements in the questionnaire were significantly observed in the respondents' experience. Cronbach's alpha was adopted to validate the survey's reliability and consistency.

Recognizing the shortcomings of a stand-alone quantitative approach, the researchers incorporated Focus Groups 3 and 4 in their research design to critique the preliminary output from the final survey instrument because stories and personal experiences of a qualitative nature helped the researchers to form a better understanding of the data and conceptual model that was established (Creswell 1994). Quantitative data were mined using content analysis and coding devised by the research team (Robson 1993; Stewart and Shamdasani 1990; Collis and Hussey 2003).

Accordingly, the final analysis was a mixed method of both quantitative (final survey instrument) and qualitative techniques (Focus Groups 3 and 4) that were triangulated (Cameron et al. 2015; Creswell 2015). This effectively closed the research loop (Creswell 1994).

\section{Results and Discussion}

The main objectives of this paper were to identify the presence of psychological contracts in construction project teams and to describe the affect that psychological contracts have on organizational teams in procurement delivery.

\subsection{Conceptual Model}

As described in the literature review, previous models of PCs displayed a relationship of exchange between an organization and an employee. They identified the type of contract and other background factors from an employee's perspective - for example, motivation, innovative behavior, and commitment (Guest and Conway 2005). Background variables included a range of individual 
biographical and occupational factors, including type of employment contract, possible variations in orientations toward work, and levels of job involvement. Organizational variables included the human resource practices in place that might help to shape levels of trust and fairness.

Adapting Guest and Conway's (2005) work, with input from discussions in Focus Groups 3 and 4, a conceptual model, The Model of PCs in Construction, was developed and is shown in Fig. 2. The model includes the Unwritten Agreement and Unwritten Contracting Behaviors that form the PC in construction. The label numbers in each construct match the question numbers in the survey. An explanation follows.

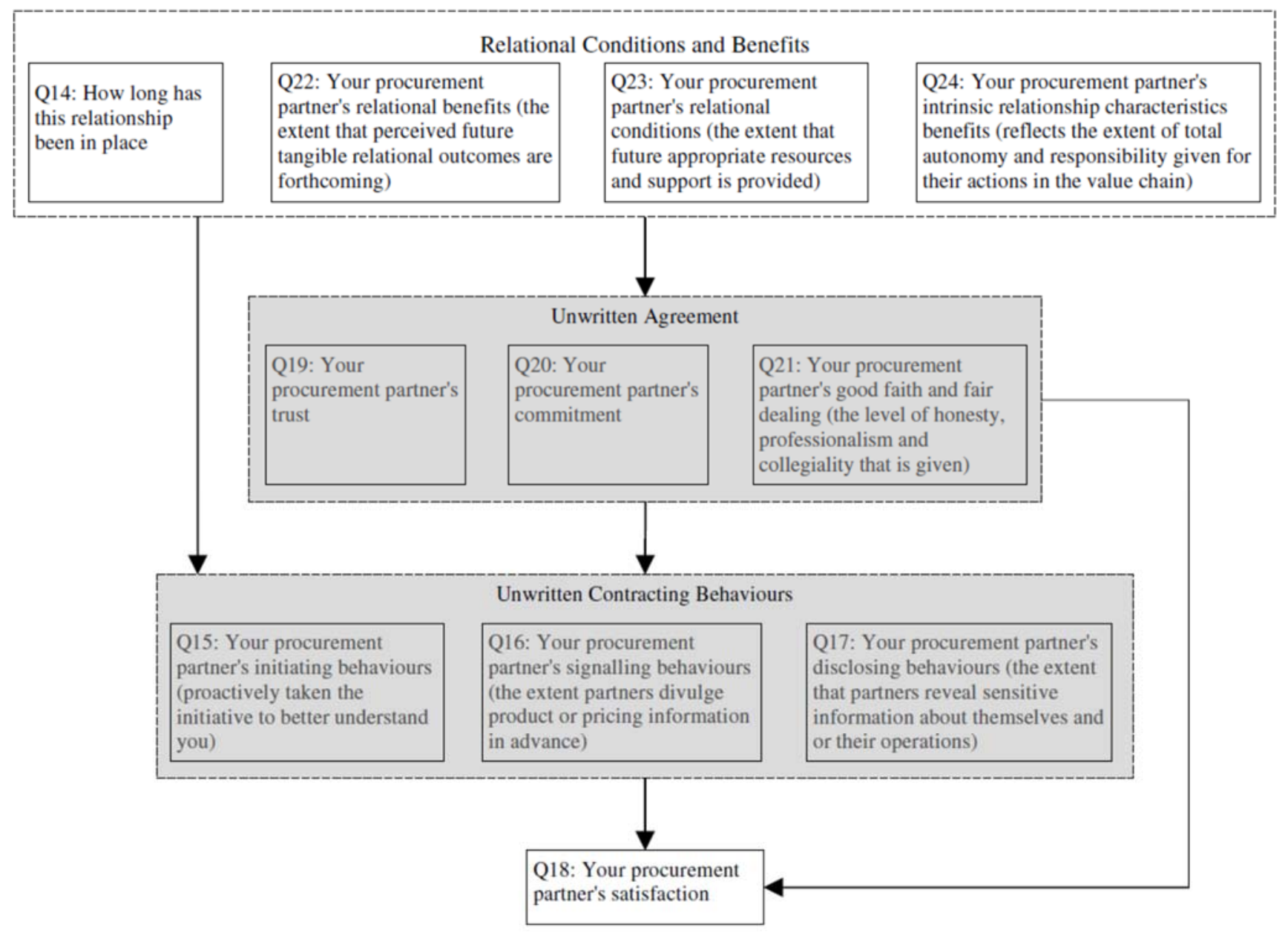

Fig. 2. Conceptual model of the PC in procurement

As a preliminary to this section, the general demographics of the respondents are delineated, identifying the characteristics of the sample and their respective project environments. With regard to sample validity, 53 sets of valid responses were received from a purposive sample of industry practitioners that met the purposive criteria. The general convention accepted for this research is that a sample size greater than 30 is considered acceptable (Nunnally 1978); because the research sample size of 53 exceeded 30, it is valid. In addition, Cronbach's alpha of the research instrument is 0.961 , suggesting that the responses have high internal consistency (Nunnally 1978). It is therefore concluded that these data are reliable and further statistical analyses can be conducted. 


\subsection{General Demographics and Background}

Most respondents were male, with less than 10\% female (9.4\%). Approximately $54.7 \%$ of respondents were $40-59$ years of age, $35.8 \%$ were $21-39$ years old, and only $9.4 \%$ were 60 or more years old. Nearly $23 \%$ respondents had more than 30 years of experience in project delivery $(22.6 \%)$, $15.1 \%$ of the respondents had 26-30 years of experience, and $11.3 \%$ had $21-25$ years of experience, so the respondents were experienced in their roles. Approximately $42 \%$ of respondents described themselves as project managers, with a further $17 \%$ identifying themselves as general managers; the balance were contracts administrators, engineers, site managers, or buyers. Approximately 58\% worked from their headquarters, $26 \%$ worked from a regional office, and $14 \%$ worked on site. Approximately $62 \%$ of the respondents were from the private sector, with the balance from the public sector. When asked about their organization's turnover nearly $60 \%$ of respondents indicated that their organization turned over more than A $\$ 200$ million per annum within organisations that employed 100-500 staff.

The respondents were asked to reflect upon a recent project while answering the questionnaire. Approximately $38 \%$ referred to projects with a contract values of $A \$ 1-A \$ 25$ million, with a further $23 \%$ referring to projects with contract values of A $\$ 25-\mathrm{A} \$ 100$ million. Essentially, the reference projects upon which the respondents were reflecting were large. The respondents were asked to identify the type of facility and delivery method used. For the former, a well-regarded pricing book by Rawlinsons (2015) was utilized to identify the anchor-point descriptive used; for the latter, a catalogue of typical procurement methods used for project delivery gleaned from established journal articles, books, and government papers was made available for the respondents' consideration (Love et al. 2009). Responses are presented in Tables 1 and 2, respectively. These two tables suggest that the sample deliberated about private-sector commercial projects delivered equally between traditional and integrated project delivery.

Table 1. Type of Facility (Grouped)

\begin{tabular}{lcccc}
\hline Type of facility & Frequency & Percentage & $\begin{array}{c}\text { Valid } \\
\text { percentage }\end{array}$ & $\begin{array}{c}\text { Cumulative } \\
\text { percentage }\end{array}$ \\
\hline Administration & 8 & 15.1 & 15.7 & 15.7 \\
Education & 10 & 18.9 & 19.6 & 35.3 \\
Infrastructure & 11 & 20.8 & 21.6 & 56.9 \\
Commercial & 22 & 41.5 & 43.1 & 100.0 \\
Valid total & 51 & 96.2 & 100.0 & - \\
Missing & 2 & 3.8 & - & - \\
Total & 53 & 100.0 & - & - \\
\hline
\end{tabular}

Table 2. Procurement (Groups)

\begin{tabular}{lcccc}
\hline Type of procurement & Frequency & Percentage & $\begin{array}{c}\text { Valid } \\
\text { percentage }\end{array}$ & $\begin{array}{c}\text { Cumulative } \\
\text { percentage }\end{array}$ \\
\hline Separated (traditional) & 29 & 54.7 & 56.9 & 56.9 \\
Packaged (integrated) & 17 & 32.1 & 33.3 & 90.2 \\
Collaborative (relational) & 5 & 9.4 & 9.8 & 100.0 \\
Valid total & 51 & 96.2 & 100.0 & - \\
Missing & 2 & 3.8 & - & - \\
Total & 53 & 100.0 & - & - \\
\hline
\end{tabular}

One-sample t-test results of the particular question sets that were found to be significant are presented in Table 3. 
Table 3. One-Sample T-Test of Each Question

\begin{tabular}{|c|c|c|c|c|}
\hline $\begin{array}{l}\text { Question } \\
\text { number }\end{array}$ & Question text & Mean & T-value & Significance \\
\hline Q17 & $\begin{array}{l}\text { Please check the box adjacent to each statement that reflects your perception of your procurement partner's } \\
\text { disclosing behaviors (the extent that partners reveal sensitive information about themselves and or their } \\
\text { operations) whilst working with you on a recent project }\end{array}$ & - & - & - \\
\hline Q17-2 & In the project, our major partner keeps me informed of new developments & 3.5094 & 4.269 & 0.000 \\
\hline Q17-3 & In the project, our major partner tends to sidestep any talk about weaknesses in their organization & 3.4528 & 3.091 & 0.003 \\
\hline Q17-5 & In the project, our major partner communicates well their expectations of my organization & 3.4906 & 3.465 & 0.001 \\
\hline Q18 & $\begin{array}{l}\text { Please check the box adjacent to each statement that reflects your perception of your procurement partner's } \\
\text { satisfaction whilst working with you on a recent project }\end{array}$ & - & - & - \\
\hline Q18-1 & In the project, our major partner is committed to my overall relationship with them & 3.5094 & 3.665 & 0.001 \\
\hline Q18-2 & In the project, our major partner wishes there were more partners like us & 3.4151 & 3.409 & 0.001 \\
\hline Q18-3 & In the project, our major partner would like our relationship with them to continue in the coming years & 3.7736 & 6.837 & 0.000 \\
\hline Q18-4 & In the project, our major partner feels it is a pleasure working with me & 3.4906 & 4.010 & 0.000 \\
\hline Q18-5 & In the project, our major partner feels there is always some problem with our relationship & 2.5472 & -3.145 & 0.003 \\
\hline Q19 & $\begin{array}{l}\text { Please check the box adjacent to each statement that reflects your pereeption of your procurement partner's } \\
\text { trust whilst working with you on a recent project }\end{array}$ & - & - & - \\
\hline Q19-1 & In the project, our major partner is reliable and they do what they say they will & 3.3774 & 2.430 & 0.019 \\
\hline Q19-7 & In the project, and major partner has high integrity & 3.3585 & 2.467 & 0.017 \\
\hline Q20 & $\begin{array}{l}\text { Please check the box adjacent to each statement that reflects your perception of your procurement partner's } \\
\text { commitment whilst working with you on a recent project }\end{array}$ & - & - & - \\
\hline Q20-1 & In the project, our major partner is something that $\mathrm{I}$ am dedicated to & 3.7170 & 5.896 & 0.000 \\
\hline Q20-2 & In the project, our major partner is very important & 4.1321 & 10.181 & 0.000 \\
\hline Q20-3 & In the project, our major partner is of little significance & 1.8113 & -9.853 & 0.000 \\
\hline Q20-4 & In the project, our major partner is something to be maintained indefinitely & 3.6792 & 4.967 & 0.000 \\
\hline Q20-6 & In the project, our major partner is something that I really care about & 3.5472 & 4.184 & 0.000 \\
\hline Q20-7 & In the project, our major partner deserves maximum attention & 3.7925 & 5.842 & 0.000 \\
\hline Q21 & $\begin{array}{l}\text { Please check the box adjacent to each statement that reflects your perception of your procurement partner's } \\
\text { good faith and fair dealing (the level of honesty, professionalism and collegiality that is given) whilst } \\
\text { working with you on a recent project }\end{array}$ & - & - & - \\
\hline Q21-1 & Our major partner promised a collaborative work environment between our organizations & 3.7736 & 6.480 & 0.000 \\
\hline Q21-2 & Our major partner promised candid and open feedback within our relationship & 3.7925 & 6.686 & 0.000 \\
\hline Q21-3 & Our major partner promised respect for our organizations efforts within the relationship & 3.7170 & 6.209 & 0.000 \\
\hline Q21-4 & Our major partner promised a cooperative working relationship between our organizations & 3.9245 & 10.936 & 0.000 \\
\hline Q21-5 & Our major partner promised honest treatment towards our organization in the relationship & 3.8491 & 8.611 & 0.000 \\
\hline Q21-6 & Our major partner promised professional and collegiality directed toward our organization & 3.9615 & 9.371 & 0.000 \\
\hline Q22 & $\begin{array}{l}\text { Please check the box adjacent to each statement that reflects your perception of your procurement partner's } \\
\text { relational benefits (the extent that perceived future tangible relational outcomes are forthcoming) whilst } \\
\text { working with you on a recent project }\end{array}$ & - & - & - \\
\hline Q22-4 & Our major partner promised incentives linked to their organization's performance & 2.6981 & -2.412 & 0.019 \\
\hline Q23 & $\begin{array}{l}\text { Please check the box adjacent to each statement that reflects your perception of your procurement partner's } \\
\text { relational conditions (the extent that future appropriate resources and support is provided) whilst working } \\
\text { with you on a recent project }\end{array}$ & - & - & - \\
\hline Q23-1 & Our major partner promised the tools necessary for our organization to perform its role effectively & 3.3208 & 2.998 & 0.004 \\
\hline Q23-2 & Our major partner promised an environment that promotes the opportunity for our organization to learn & 3.3396 & 3.261 & 0.002 \\
\hline Q23-4 & Our major partner promised a clean and safe work environment for our organization to operate in & 3.5660 & 5.335 & 0.000 \\
\hline Q23-6 & Our major partner promised further training for employees within our organization & 2.6226 & -3.375 & 0.001 \\
\hline Q24 & $\begin{array}{l}\text { Please check the box adjacent to each statement that reflects your perception of your procurement partner's } \\
\text { intrinsic relationship characteristics benefits (reflects the extent of total autonomy and responsibility given } \\
\text { for their actions in the value chain) whilst working with you on a recent project }\end{array}$ & - & - & - \\
\hline Q24-1 & Our major partner promised a relationship role that is interesting to our organization & 3.4906 & 4.762 & 0.000 \\
\hline Q24-2 & Our major partner promised a meaningful role for our firm within the overall relationship & 3.4528 & 4.130 & 0.000 \\
\hline Q24-4 & Our major partner promised a role that is challenging to our organization & 3.3774 & 3.281 & 0.002 \\
\hline Q24-5 & Our major partner promised a role that has high levels of responsibility & 3.6415 & 5.312 & 0.000 \\
\hline
\end{tabular}

\subsection{Relational Conditions and Benefits}

\section{Length of Relationship}

Question 14 asked respondents to disclose the length of the relationship they had with the project group that they would be considering; Table 4 shows that the length of relationships in the projects identified by the respondents was relatively short $-62.5 \%$ of respondents reported these relationships were less than three years. 
Table 4. Length of Relationship (Grouped)

\begin{tabular}{lcccc}
\hline Length of relationship & Frequency & Percentage & $\begin{array}{c}\text { Valid } \\
\text { percentage }\end{array}$ & $\begin{array}{c}\text { Cumulative } \\
\text { percentage }\end{array}$ \\
\hline $\begin{array}{l}\text { Relationship is 3 years } \\
\text { or less }\end{array}$ & 30 & 56.6 & 62.5 & 62.5 \\
$\begin{array}{l}\text { Relationship is over } \\
3 \text { years }\end{array}$ & 18 & 34.0 & 37.5 & 100.0 \\
Valid total & 48 & 90.6 & 100.0 & - \\
$\begin{array}{l}\text { Missing } \\
\text { Total }\end{array}$ & 5 & 9.4 & - & - \\
\hline
\end{tabular}

Despite their considerable experience described earlier, the transient nature of the construction sector and its actors is observed to be a meaningful characteristic that affects the relationship. As Davis and Love (2011) noted, relationship development is an important antecedent to relationship maintenance that requires particular interventions.

\section{Relational Benefits}

Question 22 reviewed relational benefits; the question was adapted from Rousseau's measures to determine the extent to which perceived future tangible relational outcomes - for example, future projects - were promised by a major partner (Rousseau 1996, 1998). In particular, respondents were asked to reflect on incentives linked to their organization's performance. Determined to be a significant construct by the respondents (Table 3) and subsequently discussed in Focus Groups 3 and 4 , the term promise was identified as too strong a word for use in a construction industry context; it was suggested by participants that a promise "is more implied rather than stated - an 'implied undertaking' if you like..." A respondent used the example that "giving a good price is still a long way from any guarantees to win future work," the implication being that future work is still going to be measured against performance and competition. This relates to a later point regarding commitment that appears as a PC construct in the proposed model.

\section{Resources and Support}

Question 23 determined the respondents' views of their relational partners' inclination to provide appropriate resources and support with regard to organizational learning, a safe working environment, and the overall tools necessary to effectively undertake their respective roles. In determining the significance of these questions the sample followed Rousseau and Davis (2005). Relational conditions reflect the extent to which inputs of resources and support are provided by the project owner to help the project organization perform in their own functions.

\section{Autonomy and Responsibility}

Question 24 dealt with relational contracts and benefits. These were found to be of significance by the respondents, who considered autonomy and overall responsibility in the value chain. Using an adaptation of a survey instrument from Rousseau's (1996) previous work, the respondents were directed to reflect on constructs including interesting ("a relationship role that is interesting to our organisation"), meaningful ("major partner promised a meaningful role for our firm within the overall relationship"), challenging ("promised a role that is challenging to our organization") and responsible ("major partner promised a role that has high levels of responsibility").

At its core, a personal deal may be described as affecting an individual's motivation. Providing a meaningful, challenging, and responsible role motivates construction stakeholders to a stimulating 
outcome, as indicated by Dainty and Loosemore (2012). A positive PC will offer scope to an individual to be creative, to innovate, and to be part of something that is of long-term impact and will last (Dainty and Loosemore 2012, p. 258). For example, the often-used expression "yes, that's one of my buildings," serves to support this argument. In addition, Walker and Lloyd-Walker (2015) showed growing evidence that the use of a set of high commitment practices is likely to be associated with a range of positive outcomes. These positive attributes lead to better than bestpractices outcomes and overall process and relational success (Walker et al. 2017). Following this, a contractor can benefit from higher levels of productivity and reduced cost in the process, aligned with good levels of quality and accountability (Walker and Lloyd-Walker 2015; Guest and Conway 1998).

In the conceptual model (Fig. 2) it is suggested that relational conditions and benefits are antecedents of the PC (highlighted in grey). In the foregoing discourse the respondents were shown to identify relational benefits, resources, support, autonomy, and responsibility as significant constructs. Focus Groups 3 and 4 supported the concepts.

\subsection{Psychological Contracts: Unwritten Agreement}

In the conceptual model (Fig. 2), the PC is highlighted in grey. The research suggests that the PC in construction procurement contains constructs of trust (Q19), commitment (Q20), and professionalism and collegiality (Q21).

\section{Trust}

Questions related to trust (Q19) were derived from Morgan and Hunt's (1994) scales specifically developed to reveal perceptions of the procurement partner's trust while working on a recent project. The measures of trust captured the level of reliability (they do what they say) and integrity. Trusting behaviour that occurs in PCs has been extensively researched by Dabos and Rousseau (2013) who suggested that PCs may exist between an individual and groups or interdependent organizations. However, despite extensive research, the relationship between an individual and an organization is somewhat uncertain (Conway and Briner 2005). In a trusting and integrated procurement relationship - for example, an alliance or PPP - stakeholders are able to focus on essential long-term benefits (Davis and Love 2011). These long-term benefits provide, among other things, enhanced competitiveness/innovation and productivity.

Interestingly, trust is aligned very closely with commitment (Q20). Existing survey scales were adapted to measure commitment and the respondents' beliefs about maintaining relationships. Morgan and Hunt (1994) suggested that when in alignment, commitment and trust maintain relationship investments, are crucial to complex integrated project environments, and engender cooperation within the team. Commitment and trust support long term engagement typically required in more advanced/mature project delivery methodologies. Once again, alliance or PPP delivery systems display these attributes. Participants in Focus Groups 3 and 4 suggested that the combination of commitment and trust promotes efficiency, productivity, and effectiveness that lead directly to behaviors that are conducive to long-term relationships and process success. Expanding on the interrelated nature of the constructs under discussion, it is suggested that trust and disclosing behaviours (see Q17) are closely aligned and manifest in three areas:

- People - the extent to which project delivery stakeholders are prepared to disclose privileged information and the nature of the information disclosure as a signal of good faith. As indicated subsequently in the discussion on confidential information sharing (see Q17), contracting parties 
in a procurement relationship provide tangible evidence that they are willing to make themselves vulnerable in their attempt to help obtain a desired goal.

- Organization - the willingness of a supplier/contractor to provide special equipment or adapt existing processes to meet a buyer's needs is fundamental to successful procurement. Enhancing close engagement cements the relationship required between the stakeholders. The cost of changes to meet a buyer's needs may be considerable, and customization provides evidence that the supplier of the service can be relied upon.

- Process - outcome of past ventures, length of a relationship, and documented business records provide predictability to the process between the partners in a relationship and provides a framework for ongoing mutually beneficial interaction.

\section{Commitment}

Question 20's commitment scales were adapted from Gundlach et al. (1995) to measure perceptions of partnership commitment. It was suggested that opportunism moderates commitment. There is much that catalogues the adversarial nature of the construction industry; for example, a review of the Scopus database identified several examples (e.g., Boukendour and Hughes 2014; Eriksson 2010; Rose and Manley 2014; Smiley et al. 2014).

As discussed previously, commitment is closely aligned to trust - it is essential to long-term relationships and follows the desire of contracting parties that remaining in the relationship would provide better outcomes than not. Commitment is considered to be close to mutuality, loyalty, and the forsaking of others, and is clearly distinguishable in long-term relationships (Gundlach et al. 1995). In focus group meetings, where the findings of the quantitative survey were explained, participants indicated that commitment was linked closely to future work. Upon reflection, with regard to opportunism, they referred to a three tender rule. This was described as a rational checkfor example, after a period of time by those within the team, most particularly the lead client, may require a more stringent tender process to check on aspects of value for money. In research into alliance relationship building, Davis (2005), established similar traits in relationship-building models.

\section{Professionalism and Collegiality}

Gundlach et al. (1995) suggest that relational social norms (staying together, mutual benefit and trust, and accommodating one another) are pivotal and underpin the commitment process. To prompt respondents to reflect on their procurement partner's good faith and fair dealing (the level of honesty, professionalism, and collegiality), Question 21 enquired whether a collaborative work environment, candid and open feedback, respect, a cooperative working relationship, honest treatment, and professional collegiality were perceived to be significant constructs by the respondents to the survey.

Reflective comments from Focus Groups 3 and 4 suggested these questions should be related to ethical considerations that in a mature organization underpin professional relationships. It was suggested that these attributes are largely driven by professional bodies or esteemed institutions that provide, among other things, continued professional development for the individuals within the delivery team.

\subsection{Psychological Contracts: Unwritten Contracting Behaviors}

Question 17 was adapted from Leuthesser and Kohli (1995) to assess the perception of a procurement partners' disclosing behaviors and the extent to which partners reveal sensitive 
information about themselves and all of their operations. Significant responses occurred where questions focussed on information disclosure ("partner keeps informed of new developments"), candid dialogue about the organisation ("sidestep any talk about weakness") (Note: this was transformed into a positive question for data analysis), and communication concerning expectations management ("communicates well their expectations of my organisation"). In Focus Groups 3 and 4 it was determined that in a project environment, from the earliest stages of engagement there would be an expectation that a broad spectrum of information would be disclosed in the normal course of conducting business. However, sensitive information - for example, when at the time of tender a contractor would be required to provide Methods of Work statements to comply with safety and quality legislation - in the wrong hands could compromise a relationship's development; in PC terms, this would be the catalyst of a breach (Rayton and Yalabik 2014). Innovation and productivity improvement arising from these documents in the hands of competition could prejudice competitive advantage and possibly project success. Later, in the implementation of a complex piece of infrastructure following tender negotiation or a change of management, where robust negotiation and candid dialogue would inevitably take place, glimpses into the internal workings of the organisation not normally revealed to others could conceivably be provided. Leuthesser and Kohli (1995) suggested that in some instances this eventuality potentially places a contractor at risk and relies on a level of mutual trust within the delivery team to avoid misuse. Indeed, literature on negotiation (e.g., Voordijk et al. 2013) shows that disclosing behavior leads to greater satisfaction and drives risk moves that are based on the assumption that partners will not behave opportunistically (Morgan and Hunt 1994). Similarly, Davis and Love (2011) found that contracting parties, while undertaking their business with their eyes open, have a tendency toward trusting behavior and expect it to be reciprocated in their business dealings. Leuthesser and Kohli (1995) found that disclosing behaviors are strongly related to buyer satisfaction; this suggests that the respondents were conscious of the importance of disclosing behavior and were completely aware of its association with trust, and that it formed a leading indicator of client satisfaction. Initiating and signalling behaviors were discussed by Focus Groups 3 and 4 in association with trust and commitment and were described as "noteworthy behaviours associated with the PC."

It is suggested that antecedents of the PC together with the content of the PC leads to satisfaction. The next section discusses the respondents' views on satisfaction through surveys and Focus Groups 3 and 4.

\subsection{Satisfaction}

Question 18 was adapted from Leuthesser and Kohli (1995) with reference to Morgan and Hunt (1994), who investigated the nature of relationship marketing. The question sought an insight into the respondent's perception of their procurement partner's satisfaction whilst working with them on a recent project. The question may be paraphrased as a commitment to an overall relationship that would continue in the forthcoming years, identified as a pleasurable experience with few problems. Leuthesser and Kohli (1995) suggested that unwritten contracting behaviors (Fig. 2; Q15-Q17, initiating, signalling, and disclosing behaviors) improved buyer satisfaction. Discussions with Focus Groups 3 and 4 supported this and noted a link between these behaviors and satisfaction, which they suggested to be stronger when the project output is important. Importantly, respondents identified large-value projects up to \$A25 million and dynamic construction environmental factors in their demographic responses. Accordingly, satisfaction was regarded as an appropriate outcome of the PC model. 


\section{Closing Comments}

The conceptual model identifies relational conditions that include past relationships and future appropriate resources and support, and it identifies relational benefits that consist of perceived future tangible relational outcomes and intrinsic relationship characteristics benefits. Through the PC (grey sections in Fig. 2) of Unwritten Agreement and Unwritten Contracting Behaviors, these conditions and benefits lead to the procurement partners' changed levels of satisfaction. With this knowledge and awareness, construction procurement partners can better predict their relationships development and maintenance in projects.

\section{Conclusions}

The initial aim of this study was to determine the presence of PCs in construction projects and describe the effect that PCs have on organizational teams in procurement delivery. A literature review of PCs was conducted and a conceptual model was proposed following input from the industry in response to a detailed questionnaire and two focus group sessions. Two additional followup focus group sessions reviewed the preliminary output from the questionnaire and supported the model and added depth to its structure. It is apparent that enabling factors of relational conditions and benefits form antecedents to PC constructs that appear to affect relationship development and maintenance and consequently affect satisfaction.

This study provides a greater understanding of the significance of implications for the manner in which managerial decision makers can model the customer-firm relationship because trust and commitment, described as critical components of the PC, are essential elements to the development and maintenance of mutual relationships.

Future research should compare the traditional PC with the relationship PC in procurement delivery. A further associated paper is proposed to set out PC theory and delivers a theoretical model of the PC in construction delivery identifying correlation between variables explained in this paper.

\section{Limitations}

Several limitations of the survey are acknowledged. It may be suggested that the small sample size reduced the generalizability of the outcomes to some degree, and it could be argued that their purposive characteristics compounded this with a limited breadth of construction delivery. However, this may be mitigated to some degree by the experience that was displayed by the respondents. The focus of the research - considering PCs from a construction perspective - is novel, so there was limited empirical data on the construction sector on which to draw. However, the authors believe that the foregoing research will provide a fruitful pool of discourse on which other researchers can build.

\section{Acknowledgments}

Special thanks to K. Cadman and R. Le Goff for their assistance in compiling the literature review. The authors also thank the Faculty of Engineering and Built Environment for its financial support through the Strategic Pilot Grant Scheme (2014) that enabled completion of this research project. Special gratitude is also extended to those from the construction industry who kindly participated in the focus groups and responded to the questionnaire survey reported in this paper. 


\section{References}

Anderson, J. C., and Narus, J. A. (1998). "Ideas at work: Business marketing: Understand what customers value.” Harv. Bus. Rev., 76(6), 53-65.

Anderson, N., and Schalk, R. (1998). "The psychological contract in retrospect and prospect." J. Organiz. Behav., 19(S1), 637-647.

Arnold, J. (1996). “The psychological contract: A concept in need of closer scrutiny?” Eur. J. Work Organiz. Psychol., 5(4), 511-520.

Australian Bureau of Statistics. (2012). "Year book Australia, 2012." ABS Catalogue No. 1301.0, Canberra, Australia.

Blancero, D., and Ellram, L. (1997). "Strategic supplier partnering: A psychological contract perspective.” Int. J. Phys. Distrib. Logist. Manage., 27(9/10), 616-629.

Boukendour, S., and Hughes, W. (2014). "Collaborative incentive contracts: Stimulating competitive behaviour without competition.” Constr. Manage. Econ., 32(3), 279-289.

Bresnen, M. (2009). "Living the dream? Understanding partnering as emergent practice." Constr. Manage. Econ., 27(10), 923-933.

Bryman, A. (2004). Social research methods, Oxford University Press, Oxford, U.K.

Cameron, R., Sankaran, S., and Scales, J. (2015). "Mixed methods use in project management research.” Project Manage. J., 46(2), 90-104.

CIPD (Chartered Institute of Personnel and Development). (2003). "Managing the psychological contract." $\langle\mathrm{http}: / / \mathrm{www} . c i p d . c o . u k /$ subjects/empreltns/psycntrct/psycontr.htm?IsSrchRes=1 (Aug. 20, 2014).

Collis, J., and Hussey, R. (2003). Business research, Palgrave MacMillan, Basingstoke, U.K.

Conway, N., and Briner, R. (2005). Understanding psychological contracts at work: A critical evaluation of theory and research, Oxford University Press, Oxford, U.K.

Creswell, J. (1994). Research design-Qualitative and quantitative approaches, Sage Publications, Thousand Oaks, CA.

Creswell, J. (2015). A concise introduction to mixed methods research, Sage Publications, Thousand Oaks, CA.

Cutcher, L. (2008). "Service sells: Exploring connections between customer service strategy and the psychological contract.” J. Manage. Organiz., 14(2), 116-126.

Dabos, G. E., and Rousseau, D. M. (2013). "Psychological contracts and informal networks in organizations: The effects of social status and local ties." Human Resour. Manage., 52(4), $485-510$.

Dainty, A. R. J., and Loosemore, M. (2012). Human resource management in construction: Critical perspectives, Routledge, London.

Dainty, A. R. J., Raiden, A. B., and Neale, R. H. (2004). "Psychological contract expectations of construction project managers.” Eng. Constr. Archit. Manage., 11(1), 33-44.

Davis, P. R. (2005). "The application of relationship marketing to construction." Ph.D. thesis, Royal Melbourne Institute of Technology, Melbourne, Australia.

Davis, P. R., and Love, P. E. D. (2011). "Alliance contracting: Adding value through relationship development.” Eng. Constr. Archit. Manage., 18(5), 444-461.

Davis, P. R., and Walker, D. H. T. (2009). "Building capability in construction projects: A relationship-based approach.” Eng. Constr. Archit. Manage., 16(5), 475-489.

Deery, S. J., Iverson, R. D., andWalsh, J. T. (2006). “Toward a better understanding of psychological contract breach: A study of customer service employees.” J. Appl. Psychol., 91(1), 166-175.

Eriksson, P. E. (2010). "Partnering: What is it, when should it be used, and how should it be implemented?" Constr. Manage. Econ., 28(9), 905-917.

Guest, D. E., and Conway, N. (1997). Employee motivation and the psychological contract, Institute of Personnel and Development, London. 
Guest, D. E., and Conway, N. (1998). Fairness at work and the psychological contract, Institute of Personnel and Development (IPD), London.

Guest, D. E., and Conway, N. (2002). "Communicating the psychological contract: An employer perspective.” Human Resour. Manage. J., 12(2), 22-38.

Guest, D. E., and Conway, N. (2004). Employee well-being and the psychological contract, CIPD, London.

Guest, D. E., and Conway, N. (2005). "The impact of new forms of employment contract on motivation and innovation." Economic and Social Research Council, Swindon, U.K.

Gundlach, G. T., Achrol, R. S., and Mentzer, J. T. (1995). "The structure of commitment in exchange." J. Marketing, 59(1), 78.

Hill, J. A., Eckerd, S., Wilson, D., and Greer, B. (2009). "The effect of unethical behavior on trust in a buyer-supplier relationship: The mediating role of psychological contract violation." J. Oper. Manage., 27(4), 281-293.

Kingshott, R. P. J., and Pecotich, A. (2007). "The impact of psychological contracts on trust and commitment in supplier distributor relationships." Eur. J. Marketing, 41(9/10), 1053-1072.

Krueger, R. A., and Casey, M. A. (2000). Focus groups: A practical guide for applied research, Sage Publications, Thousand Oaks, CA.

Leuthesser, L., and Kohli, A. K. (1995). "Rational behavior in business markets: Implications for relationship management." J. Bus. Res., 34(3), 221-233.

Ling, F. Y. Y., Ke, Y., Kumaraswamy, M. M., and Wang, S. (2014). "Key relational contracting practices affecting performance of public construction projects in China." J. Constr. Eng. Manage., 10.1061/(ASCE)CO.1943-7862.0000781, 04013034.

Lloyd-Walker, B. M., Mills, A. J., and Walker, D. H. T. (2014). "Enabling construction innovation: The role of a no-blame culture as a collaboration behavioural driver in project alliances." Constr. Manage. Econ., 32(3), 229-245.

Love, P., Davis, P., Baccarini, D., Wilson, G., and Lopez, R. (2009). "Capital works procurement: The selection of a building procurement method." Cooperative Research Centre for Construction Innovation, CRC Construction Innovation, Brisbane, Australia.

Love, P., Edwards, D., Watson, H., and Davis, P. (2010). "Rework in civil infrastructure projects: Determination of cost predictors." J. Constr. Eng. Manage., 10.1061/(ASCE)CO.19437862.0000136, 275-282.

Macneil, I. R. (1973). “The many futures of contracts.” South. California Law Rev., 47(3), 691-816.

Macneil, I. R. (1978). "Contracts: Adjustment of long-term economic relations under classical, neoclassical, and relational contract law." Northwestern Univ. Law Rev., 72(6), 854-905.

Morgan, R., and Hunt, S. (1994). “The commitment-trust theory of relationship marketing.” J. Marketing, 58(3), 20-38.

Newaz, M. T., Jefferies, M., Davis, P., and Pillay, M. (2016). "Using the psychological contract to measure safety outcomes on construction sites." Proc., 32nd Annual ARCOM Conf., P. W. Chan and C. J. Neilson, eds., Association of Researchers in Construction Management, Manchester, U.K.

Ning, Y., and Ling, F. Y. Y. (2015). "The effects of project characteristics on adopting relational transaction strategies." Int. J. Project Manage., 33(5), 998-1007.

Nunnally, J. C. (1978). Psychometric theory, McGraw-Hill, New York.

Productivity Commission. (2014). "Public infrastructure, inquiry." Rep. No. 71." Commonwealth of Australia, Canberra, Australia.

Raiden, A., Dainty, A., and Neale, R. (2009). Employee resourcing in the construction industry: Strategic considerations and operational practice, Taylor and Francis, London.

Rawlinsons. (2015). Rawlinsons construction cost guide, Rawlinsons Publishing, Rivervale, Australia. 
Rayton, B. A., and Yalabik, Z. Y. (2014). "Work engagement, psychological contract breach and job satisfaction.” Int. J. Human Resour. Manage, 25(17), 2382-2400.

Robinson, S. L., Kraatz, M. S., and Rousseau, D. M. (1994). "Changing obligations and the psychological contract-A longitudinal-study.” Acad. Manage. J., 37(1), 137-152.

Robson, C. (1993). Real world research: A resource for social scientists and practitioner-researchers, Wiley, Oxford, U.K.

Rose, T. M., and Manley, K. (2014). "Revisiting the adoption of innovative products on Australian road infrastructure projects.” Constr. Manage. Econ., 32(9), 904-917.

Rousseau, D. M. (1990). "New hire perceptions of their own and their employers obligations-A study of psychological contracts.” J. Organiz. Behav., 11(5), 389-400.

Rousseau, D. M. (1995). Psychological Contracts in organisations, Sage Publications, Thousand Oaks, CA.

Rousseau, D. M. (1996). Psychological contract measures, Carnegie Mellon Univ., Pittsburgh.

Rousseau, D. M. (1998). “The problem of the psychological contract considered.” J. Organiz. Behav., 19(S1), 665-671.

Smiley, J. P., Fernie, S., and Dainty, A. (2014). "Understanding construction reform discourses." Constr. Manage. Econ., 32(7-8), 804-815.

Sparrow, P., and Marchington, M. (Eds.) (1998). Human resource management: The new agenda, Financial Times Pitman Publications, London.

Stewart, D. W., and Shamdasani, P. N. (1990). Focus groups theory and practice, Sage Publications, Thousand Oaks, CA.

Stiles, P., Gratton, L., Truss, C., Hope-Hailey, V., and McGovern, P. (1997). "Performance management and the psychological contract." Human Resour. Manage. J., 7(1), 57-66.

Taggart, M., Koskela, L., and Rooke, J. (2014). "The role of the supply chain in the elimination and reduction of construction rework and defects: An action research approach." Constr. Manage. Econ., 32(7-8), 829-842.

Voordijk, H., Hoezen, M., and Dewulf, G. (2013). "Formal bargaining and informal sense making in the competitive dialogue procedure-An event-driven explanation.” Int. J. Manag. Projects Bus., 6(4), 674-694.

Walker, A. (2010). "The development and validation of a psychological contract of safety scale.” J. Saf. Res., 41(4), 315-321.

Walker, A. (2013). "Outcomes associated with breach and fulfillment of the psychological contract of safety." J. Saf. Res., 47, 31-37.

Walker, A., and Hutton, D. M. (2006). "The application of the psychological contract to workplace safety.” J. Saf. Res., 37(5), 433-441.

Walker, D. H., Davis, P. R., and Stevenson, A. (2017). "Coping with uncertainty and ambiguity through team collaboration in infrastructure projects.” Int. J. Project Manage., 35(2), 180190.

Walker, D. H. T., and Lloyd-Walker, B. M. (2015). Collaborative project procurement arrangements, Project Management Institute, Newtown Square, PA.

Zumbo, B. D., and Zimmerman, D.W. (1993). "Is the selection of statistical methods governed by level of measurement?" Can. Psychol., 34(4), 390-400. 